\title{
IDENTIFIKASI KESULITAN BELAJAR TEMATIK KELAS 3 DI SD NEGERI 14 TANGERANG
}

\author{
Ina Magdalena ${ }^{1}$, Tiara Safitri ${ }^{2}$, Nurlaili Maghfiroh ${ }^{3}$, Niken Nur Yolawati ${ }^{4}$ \\ Universitas Muhammadiyah Tangerang \\ inamagdalena@umt.ac.id,tsafitri344@gmail.com .
}

\begin{abstract}
Regulation of the Minister of National Education No. 41 of 2007 binted at the use of thematic approach in the learning of grade 1 to grade 3 of elementary school (SD). Even today after the implementation of the 2013 curriculum, the thematic approach must be implemented from class 1 to grade 6 in the learning process. It is important for elementary school teachers to be able to implement thematic approaches as professional responsibilities. This study aims to: 1) analyze elementary school teachers 'understanding of the thematic approach, 2) get the profile of elementary school teachers' ability in implementing thematic approaches, and 3) find out the constraints of teachers in implementing thematic approaches in elementary schools. The research used qualitative descriptive method with research subjects of grade 3 teachers in SD Negeri Tangerang 14. Data is collected by observation and interview. Triangulation is carried out through focus group discussions between researchers, teachers, and principals. The results of the study showed that the teacher understood the thematic approach well, but in practice 1 teachers studied did not carry out the thematic approach to learning. This study also revealed that most teachers experience obstacles in implementing thematic approaches to the learning process.
\end{abstract}

Keywords: The Ability Of Teachers, Elementary School Teachers

\begin{abstract}
Abstrak: Peraturan Menteri Pendidikan Nasional Nomor 41 tahun 2007 mengisyaratkan penggunaan pendekatan tematik dalam pembelajaran kelas 1 sampai kelas 3 Sekolah Dasar (SD). Bahkan dewasa ini pasca diberlakukannya Kurikulum 2013, pendekatan tematik wajib diimplementasikan dari kelas 1 sampai kelas 6 pada proses pembelajaran. Adalah menjadi hal yang penting bagi guru SD untuk dapat melaksanakan pendekatan tematik sebagai tanggung jawab profesi. Penelitian ini bertujuan untuk: 1) menganalisis pemahaman guru SD tentang pendekatan tematik, 2) mendapatkan profil kemampuan guru SD dalam melaksanakan pendekatan tematik, dan 3) mengetahui hambatan-hambatan guru dalam mengimplementasikan pendekatan tematik di SD. Penelitian menggunakan metode deskriptif kualitatif dengan subjek penelitian guru kelas 3 di SD Negeri Tangerang 14. Data dikumpulkan dengan observasi dan wawancara. Triangulasi dilakukan melalui focus group discussion antara peneliti, guru, dan kepala sekolah. Hasil penelitian menunjukkan bahwa secara konsep guru memahami pendekatan tematik dengan baik, namun pada pelaksanaannya 1 orang guru yang diteliti tidak melaksanakan pendekatan tematik dalam pembelajaran. Penelitian ini juga mengungkapkan bahwa sebagian besar guru mengalami kendala dalam mengimplementasikan pendekatan tematik pada proses pembelajaran.
\end{abstract}

Kata Kunci: Kemampuan Guru, Guru Sekolah Dasar, Pendekatan Tematik

Fondatia : Jurnal Pendidikan Dasar

Volume 4, Nomor 2, September 2020; 222-233

https://ejournal.stitpn.ac.id/index.php/fondatia 


\section{PENDAHULUAN}

Pendidikan adalah usaha sadar dan bertujuan untuk mengembangkan kualitas manusia sebagai suatu kegiatan yang sadar akan tujuan. Maka dalam pelaksanaannya berada dalam suatu proses yang berkesinambungan dalam setiap jenis dan jenjang pendidikan, semuanya berkaitan dalam suatu sistem pendidikan yang integral, Djamarah (2002:22).

Belajar merupakan proses dasar dari perkembangan hidup manusia. Dengan belajar, manusia melakukan perubahan-perubahan kualitatif individu sehingga tingkah lakunya berkembang. Semua aktivitas dan prestasi hidup manusia tak lain adalah hasil dan belajar. Belajar itu bukan sekedar pengalaman, akan tetapi belajar adalah suatu proses dan bukan suatu hasil. Karena itu belajar berlangsung secara aktif dan integrative dengan menggunakan berbagai bentuk perbuatan untuk mencapai suatu tujuan, Soemanto (2006:104).

Penyelenggaraan pendidikan dan pengajaran mulai dari pendidikan sampai dengan perguruan tinggi hanya akan efektif jika dikelola oleh tenaga pendidikan dan guru profesional. Disamping itu juga untuk meningkatkan mutu pendidikan khususnya pendidikan terpadu diusahakan melalui penyediaan sarana dan prasarana pendidikan seperti: buku-buku paket, alat peraga dan fasilitas pengajarannya.

Pembelajaran tematik merupakan suatu usaha memadukan pengetahuan secara komprehensif dan terintegrasi.Pembelajaran terpadu di sekolah dasar membantu mengembangkan pemahaman siswa yang berakibat siswa menjadi lebih terlibat dalam pembelajaran (Slekar, et al, 2003).

Pembelajaran terpadu menggunakan tema sebagai pemersatu kegiatan pembelajaran yang memadukan beberapa mata pelajaran sekaligus dalam satu kali tatap muka, untuk memberikan pengalaman yang bermakna bagi peserta didik. Karena peserta didik dalam memahami sebuah konsep yang mereka pelajari selalu melalui pengalaman langsung dan menghubungkannya dengan konsep lain yang telah dikuasainya.

Menurut Hadi Subroto (2000:9), pembelajaran tematik adalah pembelajaran yang diawali dengan suatu tema tertentu yang mengaitkan dengan pokok bahasan lain, 
konsep tertentu dikaitkan dengan konsep lain yang dilakukan secara spontan atau direncanakan baik dalam satu bidang studi atau lebih dan dengan beragam pengalaman belajar sehingga pembelajaran menjadi semakin bermakna.

Menurut Suryosubroto, (2009: 133) "pembelajaran tematik dapat diartikan suatu kegiatan pembelajaran dengan mengintegrasikan materi beberapa mata pelajaran dalam satu tema atau topik tertentu". Lebih lanjut Sungkono (dalam Suryosubroto, 2006: 132) mengungkapkan pembelajaran tematik secara singkat diuraikan meliputi prinsip-prinsip, ciri-cirinya, pemilihan tema, dan contoh implikasinya di sekolah.

Menurut Trianto (2011: 139) pembelajaran tematik adalah pembelajaran terpadu yang menggunakan tema untuk mengaitkan beberapa mata pelajaran sehingga dapat memberikan pengalaman belajar yang bermakna kepada peserta didik. Sedangkan menurut Mamat (dalam Andi, 2013: 125) Pembelajaran tematik sebagai pembelajaran terpadu, dengan mengelola pembelajaran yang mengintegrasikan materi dari beberapa mata pelajaran dalam satu topik pembicaraan yang disebut tema. Berdasarkan beberapa pendapat di atas, kami menyimpulkan bahwa pembelajaran tematik yaitu pembelajaran yang mengintegrasikan materi dari beberapa mata pelajaran dalam satu topik pembicaraan yang disebut tema sehingga dapat memberikan pengalaman belajar yang bermakna kepada peserta didik.

\section{METODE PENELITIAN}

\section{Jenis Penelitian}

Penelitian ini menggunakan jenis penelitian kuantitatif. Dalam penelitian ini, peneliti mengumpulkan data yang diperoleh dari pengumpulan data melalui observasi, wawancara, angket dan dokumentasi.

\section{Tempat dan Penelitian}

Penelitian ini dilaksanakan di SD Negeri Tangerang 14 yang beralamatkan di Jl. Tegal Sari Raya Kota Tangerang, Banten. 


\section{Subjek Penelitian}

Subjek dalam penelitian ini adalah guru kelas III SD Negeri Tangerang 14.Siswa Kelas III dijadikan subjek penelitian utama informan kunci karena sebagai. Selain itu, guru kelas juga dipandang sebagai orang yang benar-benar mengetahui tentang data yang akan dikumpulkan. Selanjutnya kepala sekolah, guru-guru, dan beberapa siswa kelas IV juga dijadikan sumber informasi untuk mendapatkan data dan informasi sebanyak-banyaknya.

\section{Sumber Data}

Sumber data dalam penelitian ini adalah orang sebagai narasumber dan dokumentasi sebagai data pendukung. Dalam penelitian ini, nara sumber dipilih adalah guru kelas III, kepala sekolah, guru mata pelajran dan beberapa siswa kelas III. Data pendulung dalam penelitian ini adalah dokumen-dokument yang terkait dengan subjek penelitian.

\section{Teknik Pengumpulan Data}

Teknik pengumpulan data dalam penelitian menggunakan teknik observasi, wawancara, dokumentasim dan catatan lapangan.Teknik pengumpulan data dalam penelitian ini dengan melakukan wawancara terhadap guru kelas III dan kemudian melakukan observasi pelaksanaan layanan pribadi.Penelitian juga melakukan dokumentasi dan membuat catatan lapangan sebagai upaya untuk kelengkapan data. Selain itu juga penelitian yang dilakukan dengan cara memberi seperangkat pertanyaan atau pertanyaan tertulis kepada responden yaitu guru kelas III SD Negeri Tangerang 14.

\section{Instrumen Penelitian}

Dalam penelitian ini peneliti menjadi instrumen karena penelitian merupakan instrumen yang efektif untuk mengumpulkan data.Penelitian dibantu dengan instrumen panduan seperti observasi (pengamatan), pendoman wawancara, catatatn lapangan dan dokumentasi.

\section{Teknik Analisis Data}

Teknik analisis data dilakukan sesuai dengan prosedur ilmiah penelitian kualitatif. 
Dalam teknik analisis ini terdapat tiga tahapan, yaitu reduksi data,penyajian data, dan verifikasi data. Reduksi data bertujuan untuk menyederhanakan data yang abstrak menjadi sebuah rangkuman yang jelas dan terperinci. Data tersebut dihasilkan dari proses wawancara, observasi, dokumentasi, catatan lapangan. Proses selanjutnya adalah penyajian data. Penyajian data disajikan dalam bentuk kerangka atau bagan. Penyajian data merupakan proses penampilan data secara lebih sederhana dalam bentuk paparan naratif dari hasil penelitian tentang kesulitan membaca kelas III Sd Negeri Tangerang 14. Kemudian langkah terakhir adalah verifikasi data.Data yang telah diproses kemudian ditarik kesimpulan. Penyimpulan merupakan proses pengambilan intirasi data sajian yang telah terorganisir tersebut dalam bentuk pernyataan kalimat yang singkat dan padat tapi mengandung pengertian yang luas.

\section{Keabsahan Data}

Pada penelitian ini, pemeriksaan keabsahan data menggunakan uji kredibilitas dengan cara triangulasi. Langkah ini dilakukan untuk dapat meningkatkan derajat kepercayaan terhadap data penelitian yang diperoleh.Triangulasi yang digunakan pada penelitian adalah triangulasi teknik. Langkah ini dilakukan untuk menguji kredibilitas data dan dilakukan dengan cara mengecek data kepada sumber yang sama dengan teknik yang berbeda. Dalam penelitian ini teknik triangulasi dilakukan dengan cara mengecek data dengan sumber yang sama dengan teknik yang berbeda yaitu observasi, wawancara, angket, dan dokumentasi.

\section{HASIL DAN PEMBAHASAN}

Kesulitan belajar yang terjadi tematik di kelas III SD Negeri Tangerang 14 sangat variatif. Kesulitan belajar tersebut dilihat dari faktor internal dan faktor eksternal yang dialami siswa.hal itu selaras dengan pendapat Irham dan Wiyani ( 2013:254), bahwa kesulitan belajar dapat digolongkan kedalam dua golongan yaitu faktor intern (faktor dari dalam diri manusia itu sendiri) dan faktor eksternal (faktor dari luar manusia) antara lain sebagai berikut :

Faktor internal yang ditemukan oleh peneliti adalah faktor internal secara psikologis, karena faktor internal secara fisiologis tidak terjadi pada kelas III SD 
Negeri Tangerang 14 khusunya dalam pembelajaran tematik. Faktor internal tersebut adalah sikap terhadap belajar, konsentrasi belajar, rasa percaya diri, dan intelektual siswa. Dari beberapa faktor internal kesulitan belajar siswa kelas III hal tersebut diperkuat oleh pendapat Ahmadi dan Supriyono (2013:264) bahwa faktor psikologis siswa yang dapat meliputi kesulitan belajar meliputi tingkat integensi pada umumnya rendah, bakat terhadap mata pelajaran rendah, minat belajar kurang, motivasi rendah, dan kondisi kesehatan mental yang kurang baik.

Faktor internal secara psikologis antara lain sebagai berikut:

1. Faktor Internal.

a. Ciri Khas/Karekteristik Siswa.

Berdasarkan hasil observasi dapat dilihat dari kesediaan siswa untuk mencatat pelajaran, mempersiapkan buku, alat-alat tulis atau hal-hal yang diperlukan. Namun, bila mana siswa tidak memiliki minat untuk belajar, maka siswa tersebut cenderung mengabaikan kesiapan belajar.

b. Sikap Terhadap Belajar.

Sikap siswa dalam proses belajar, terutama sekali ketika memulai kegiatan belajar merupakan bagian penting untuk diperhatikan karena aktivitas belajar siswa banyak ditentukan oleh sikap siswa ketika akan memulai kegiatan belajar. Namun, bila lebih dominan sikap sebelum belajar maka siswa cenderung kurang memperhatikan atau mengikuti kegiatan belajar.

c. Motivasi Belajar.

Di dalam aktivitas belajar, motivasi individu dimanefestasikan dalam bentuk ketahanan atau ketekunan dalam belajar, kesungguhan dalam menyimak, mengerjakan tugas dan sebagainya. Umumnya kurang mampu untuk belajar lebih lama, karena kurangnya kesungguhan di dalam mengerjakan tugas. Oleh karena itu, rendahnya motivasi merupakan masalah dalam belajar yang memberikan dampak bagi ketercapaianya hasil belajar yang diharapkan.

d. Konsentrasi Belajar.

Kesulitan berkonsentrasi merupakan indikator adanya masalah belajar yang dihadapi siswa, karena hal itu akan menjadi kendala di dalam mencapai hasil 
belajar yang diharapkan. Untuk membantu siswa agar dapat berkonsentrasi dalam belajar tentu memerlukan waktu yang cukup lama, di samping menuntut ketelatenan guru.

e. Mengelolah Bahan Ajar.

Siswa mengalami kesulitan di dalam mengelolah bahan, maka berarti ada kendala pembelajaran yang dihadapi siswa yang membutuhkan bantuan guru. Bantuan guru tersebut hendaknya dapat mendorong siswa agar memiliki kemampuan sendiri untuk terus mengelolah bahan belajar, karena konstruksi berarti merupakan suatu proses yang berlangsung secara dinamis.

f. Menggali Hasil Belajar.

Bagi guru dan siswa sangat penting memperhatikan proses penerimaan pesan dengan sebaik-baiknya terutama melalui pemusatan perhatian secara optimal. Guru hendaknya berupaya mengaktifkan siswa melalui pemberian tugas, latihan, agar siswa mampu meningkatkan kemampuan dalam mengolah pesan-pesan pembelajaran.

g. Rasa Percaya Diri.

Salah satu kondisi psikologis seseorang yang berpengaruh terhadap aktivitas fisik dan mental dalam proses pembelajaran adalah rasa percaya diri. Rasa percaya diri umumnya muncul ketika seseorang akan melakukan atau terlibat di dalam suatu aktivitas tertentu di mana pikirannya terarah untuk mencapai sesuatu hasil yang diinginkannya. Hal-hal ini bukan merupakan bagian terpisah dari proses belajar, akan tetapi merupakan tanggung jawab yang harus diwujudkan guru bersamaan dengan proses pembelajaran yang dilaksanakan.

h. Kebiasaan Belajar.

Adalah perilaku belajar seseorang yang telah tertanam dalam waktu yang relatif lama sehingga memberikan ciri dalam aktivitas belajar yang dilakukan.

i. Factor Fisiologis.

Faktor fisiologi adalah factor fisik dari anak itu sendiri. seorang anak yang sedang sakit, tentunya akan mengalami kelemahan secara fisik, sehingga 
proses menerima pelajaran, memahami pelajaran menjadi tidak sempurna. Selain sakit factor fisiologis yang perlu kita perhatikan karena dapat menjadi penyebab munculnya masalah kesulitan belajar adalah cacat tubuh, yang dapat kita bagi lagi menjadi cacat tubuh yang ringan seperti kurang pendengaran, kurang penglihatan, serta gangguan gerak, serta cacat tubuh yang tetap (serius) seperti buta, tuli, bisu, dan lain sebagainya.

Faktor fisiologi adalah factor fisik dari anak itu sendiri. seorang anak yang sedang sakit, tentunya akan mengalami kelemahan secara fisik, sehingga proses menerima pelajaran, memahami pelajaran menjadi tidak sempurna. Selain sakit factor fisiologis yang perlu kita perhatikan karena dapat menjadi penyebab munculnya masalah kesulitan belajar adalah cacat tubuh, yang dapat kita bagi lagi menjadi cacat tubuh yang ringan seperti kurang pendengaran, kurang penglihatan, serta gangguan gerak, serta cacat tubuh yang tetap (serius) seperti buta, tuli, bisu, dan lain sebagainya.

2. Faktor Eksternal

Setelah membahas faktor internal kesulitan belajar siswa, faktor eksternal siswa dalam kesulitan belajar tematik juga berpengaruh terhadap hasil belajar siswa kelas III di SDNegeri Tangerang 14. Faktor ekternal tersebut adalah faktor yang muncul dari luar diri siswa. adapun faktor eksternal yang ditemukan adalah Keluarga dan teman kelompok. Hal itu selaras dengan pendapat Muhibbin Syah (2008:132), bahwa faktor eksternal (faktor dari luar diri individu) meliputi kondisi lingkungan sekitar siswa dan teman. jadi dari beberapa faktor eksternal yang ditemukan peneliti merupakan suatu kondisi yang terjadi disekitar siswa itu sendiri. Faktor ekternal yang ditemukan di kelas III SDNegeri Tangerang 14 adalah sebagai berikut :

a. Teman Sebaya.

Teman sangat berpengaruh terhadap hasil belajar, akibat dari teman yang hyper active banyak siswa disekelilingnya terpengaruh sehingga ikut bercanda pada saat pembelajaran berlangsung. Contohnya di kelas III SD Negeri Tangerang 14 , saat pembelajaran berlangsung banyak siswa yang ngobrol sendiri dengan temannya, banyak yang bercanda sendiri tanpa menghiraukan 
penjelasan guru di kelas, Akan tetapi pada hakikatnya yang menentukan bagaimana tindakan individu adalah individu itu sendiri.

Dalam faktor ini guru harus dapat memilih teman kelompok diantara semua siswa. misalnya dengan menggabungkan siswa yang berkemampuan tinggi dengan siswa yang berkemampuan lebih rendah. Dan dapat mengkondisikan kelas agar siswa tidak saling bercanda satu sama lain dan juga memotivasi siswa dalam kegiatan proses belajar mengajar.

b. Lingkungan.

Faktor lingkungan merupakan salah satu tingkat keberhasilan belajar, lingkungan yang baik mudah membuat siswa memahami pelajaran dengan baik. Begitu juga dengan lingkungan yang kurang baik seperti lingkungan tempat mabul-mabukan membuat anak susah dalam pokus belajar karena lingkungan yang kurang baik

c. Faktor Lingkungan Sekolah.

Sekolah sebagai lembaga pendidikan formal setelah keluarga dapat menjadi masalah pada umumnya, dan khususnya masalah kesulitan belajar pada siswa. Hal ini sesuai dengan pendapat yang menyatakan bahwa lingkungan sekolah dapat menjadikan faktor yang mempengaruhi kesulitan belajar seperti :

1) Cara penyajian pelajaran kurang baik.

2) Hubungan guru dan murid kurang harmonis.

3) Hubungan antara burid dengan murid itu sendiri tidak baik.

4) Bahan pelajaran yang disajikan tidak dimengerti siswa, dan

5) Alat-alat pelajaran yang tersedia kurang memadai (Ibid, 31.)

Faktor-faktor internal siswa yang mempengaruhi terhadap kesulitan belajar siswa dalam pembelajaran tematik kelas III SD Negeri 14 diantaranya dari sikap siswa terhadap belajar, konsentrasi belajar siswa, kurangnya motivasi belajar, rasa percaya diri siswa, dan intelektual siswa. Sedangkan faktor eksternal yang mempengaruhi terhadap kesulitan belajar siswa dalam pembelajaran tematik kelas IV SDN 5 Dawuhan adalah kinerja guru, faktor pendukung dan teman kelompok. 
Pembelajaran tematik adalah pembelajaran terpadu yang menggunakan tema untuk mengaitkan beberapa mata pelajaran sehingga dapat memberikan pengalaman yang bermakna serta memberikan keuntungan bagi siswa, diantaranya: (a) mudah memusatkan perhatian pada suatu tema tertentu; (b) mampu mempelajari pengetahuan dan mengembangkan berbagai kompetensi dasar antar mata pelajaran dalam tema yang sama; (c) pemahaman terhadap materi pelajaran lebih mendalam dan berkesan; (d) kompetensi dasar dapat dikembangkan lebih baik dengan mengaitkan mata pelajaran lain dengan pengalaman pribadi siswa; (e) lebih merasakan manfaat dari belajar karena materi disajikan dalam konteks tema yang jelas; (f) lebih bergairah belajar karena dapat berkomunikasi dalam situasi nyata, untuk memgembangkan suatu kemampuan dalam satu mata pelajaran sekaligus mempelajari mata pelajaran lain; (g) dapat menghemat waktu karena mata pelajaran yang disajikan dapat dipersiapkan sekaligus diberikan dalam dua atau tiga kali pertemuan, sedangkan selebihnya dapat digunakan untuk kegiatan remedial dan pengayaan.

Hasil penelitian menunjukkan bahwa permasalahan persiapan pembelajaran tematik antara lain :

1. Guru kesulitan dalam mengembangkan tema dan contoh tema tidak selalu sesuai dengan

kondisi lingkungan belajar siswa.

2. Bahan ajar yang tersedia masih menggunakan pendekatan mata pelajaran.

3. sehingga menyulitkan guru memadukan materi sesuai tema

4. Guru kesulitan cara melakukan pemetaan. bagi kompetensi dasar yang lintas semester dan Kompetensi Dasar yang tidak sesuai dengan tema.

5. Guru kesulitan dalam merumuskan keterpaduan berbagai mata pelajaran pada langkah pembelajaran dalam Rencana Pelaksanaan Pembelajaran(RPP).

Hasil penelitian bahwa kendala dalam menerapkan pembelajaran tematik adalah

1. Keterbatasan sarana dan prasarana sekolah. 
2. Keterbatasan pengetahuan guru mengenai penerapan model pembelajaran tematik.

3. Keterbatasan penggunaan model dan media pembelajaran.

4. Sulitnya mengubah cara mengajar guru.

5. Guru kesulitan dalam membuat instrumen penilaian.

Pendapat lain menurut Karli, Hilda (2012) mengatakan bahwa kendala Pembelajaran Tematik adalah sebagai berikut: (a) Perencanaan pembelajaran tematik yang memakan waktu dan tenaga yang lebih banyak mulai dari penyusunan matriks tematik, jaring laba-laba, program semester, silabus dan RPP sekaligus dibuat dalam 1 semester; (b) Tidak berurutan materi yang diajarkan kecuali Matematika dalam 1 semester; dan (c) Menyiapkan media perlu disesuaikan dengan pemilihan tema.

Beberapa cara mengatasi kendala Pembelajaran Tematik sebagai berikut :

1. Pemahamana Kurikulum beserta alat-alatnya.

2. Kerja Team Work dari para guru SD tiap jenjang untuk membuat perencanaan hingga pelaksanaan.

3. Para siswa diajak terlibat untuk menyiapkan media sesuai dengan tema, paling tidak 3 hari sebelumnya.

4. Menggunakan bahan ajar Tematik untuk membantu guru baik dari persiapan, pelaksanaan bahkan evaluasi.

Berdasarkan uraian tersebut di atas untuk mengurangi kendala dalam melaksanakan pembelajaran tematik di kelas rendah seyogianya sekolah harus menyediakan sarana pembelajaran sesuai dengan kebutuhan siswa, perlu adanya latihan khusus untuk menyusun RPP tematik dan dari pihak Diknas harus melakukan supervisi secara teratur kesekolah- sekolah.Wahyuni, V (2013) menyatakan bahwa kunci keberhasilan pembelajaran tematik terletak pada kreativitas guru mengolah tema dan potensi siswa.

Kesulitan guru dalam pembelajaran tematik di SD Negeri Tangerang 14 Pemanggilan dalam indikator faktor daya dukung adalah daya dukung dalam 
pembelajaran tematik seperti guru, peserta didik, sarana, sumber belajar, dan media pembelajaran belum memadai dalam beberapa tema pembelajaran. Hal ini disebabkan karena daya dukung dalam pelaksanaan pembelajaran tematik seperti guru, peserta didik, sarana, sumber belajar, dan media pembelajaran belum lengkap dan responden terkadang kurang memanfaatkan sarana dan media pembelajaran yang sudah ada.

\section{KESIMPULAN}

Berdasarkan Penelitian yang kita lakukan bahwa Di SD Negeri Tangerang 14 masih mengalami kesulitan belajar tematik seperti kurang pemahaman menerapkan pembelajaran tematik adalah: (a) keterbatasan sarana dan prasarana sekolah, (b) keterbatasan pengetahuan guru mengenai penerapan model pembelajaran tematik, (c) keterbatasan penggunaan model dan media pembelajaran, dan (d) sulitnya mengubah cara mengajar guru (e) Guru kesulitan membuat instrumen penilaian. Didukung kesulitan hasil belajar siswa yang disebabkan oleh faktor nternal seperti kurangnya motivasi dalam belajar, kurangpercaya diri dan lainnya dan eksternal seperti lingkungan yang tidak baik, teman, lingkungan sekolah.

\section{DAFTAR PUSAKA}

Panduanmengajar.blogspot.com/2016/02/apa-itu-pembelajaran-tematik.

Riadi, Muchlisin. 2020.Pembelajaran-tematik.

Dutaka.blogspot.com/2015/03/pembelajaran-tematik.

Faizal, Al. 2016/37-analisis-kesulitan-belajar-siswa-dalam-pembelajaran-tematik.

Arikunto, S. 2007. Penelitian Tindakan Kelas. Jakarta: Bumi Aksara.

Izkiprihidayatsdntanggaulin1.blogspot.com/2014/11/permaslahan-pembelajarantematik. 